\title{
THERAPY OF ENDOCRINE DISEASE
}

\section{Treatment of osteogenesis imperfecta in adults}

\author{
Katarina Lindahl' ${ }^{1}$, Bente Langdahl ${ }^{2}$, Östen Ljunggren ${ }^{1}$ and Andreas Kindmark ${ }^{1,3}$ \\ ${ }^{1}$ Department of Medical Sciences, Uppsala University Hospital, Ing 40, 5tr, SE-75185 Uppsala, Sweden, ${ }^{2}$ Department \\ of Endocrinology and Internal Medicine THG, Aarhus University Hospital, DK-8000 Aarhus C, Denmark and ${ }^{3}$ Science \\ for Life Laboratory, Department of Medical Sciences, Uppsala University Hospital, SE-75185 Uppsala, Sweden
}

\author{
Correspondence \\ should be addressed \\ to A Kindmark \\ Email \\ andreas.kindmark@ \\ medsci.uu.se
}

\begin{abstract}
Background: Osteogenesis imperfecta (OI) is a heterogeneous rare connective tissue disorder commonly caused by mutations in the collagen type I genes. Pharmacological treatment has been most extensively studied in children, and there are only few studies comprising adult Ol patients.

Objectives: i) To review the literature on the current medical management of OI in children and adults, and thereby identify unmet medical needs and ii) to present an overview of possible future treatment options.

Results: Individualization and optimization of OI treatment in adults remain a challenge, because available treatments do not target the underlying collagen defect, and available literature gives weak support for treatment decisions for adult patients.
\end{abstract}

Conclusions: Bisphosphonates are still the most widely used pharmacological treatment for adult Ol, but the current evidence supporting this is sparse and investigations on indications for choice and duration of treatment are needed.

\section{Introduction}

\section{General background}

Osteogenesis imperfecta (OI) is a heterogeneous disorder of connective tissues with an incidence of $1 / 15000(1,2$, 3 , 4) and disease severity spanning from subclinical osteoporosis to intrauterine lethality. Dominant mutation in collagen type $\mathrm{I}$ is the most common cause (>90\%); however, in the last decade the molecular background of several recessive, an X-linked, and a non-collagen dominant form has been reported $(5,6,7,8,9,10,11,12,13$, $14,15,16,17,18,19,20,21,22,23,24,25,26,27,28$, $29,30)$. The cardinal sign of OI is bone fragility, with subsequent fractures, deformities, and growth retardation. Most patients have a low bone mineral density (BMD), to some extent negatively correlated to clinical severity (31). Generally, the high fracture incidence observed in children with OI decreases after puberty. Collagen I is the most abundant protein in vertebrates, and is present in large quantities in many connective tissues. Thus, patients may have other signs and symptoms including blue sclerae, dentinogenesis imperfecta (DI), hearing impairment, hyperlaxity, scoliosis, and increased bruising and bleeding $(32,33,34)$.

\section{Invited Author's profile}

A Kindmark is a senior consultant at the Department of Endocrinology, Uppsala University Hospital, Uppsala, Sweden. His current areas of research interests include osteogenesis imperfecta, bone phenotypes of inborn errors of metabolism, and modulation of bone metabolism by miRNAs and gene therapy. He is the scientific secretary for the Swedish Endocrine Society, and a former president of the Swedish Osteoporosis Society.

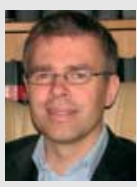

(c) 2014 European Society of Endocrinology Printed in Great Britain
Published by Bioscientifica Ltd. 
Table 1 Classification of Ol types.

\begin{tabular}{|c|c|c|}
\hline Ol type & Affected gene & Phenotype \\
\hline \multicolumn{3}{|l|}{ Dominant inheritance } \\
\hline \multicolumn{3}{|l|}{ Classical Sillence types } \\
\hline I & COL1A1 or COL1A2 & Mild, nondeforming \\
\hline II & COL1A1 or COL1A2 & Perinatal lethal \\
\hline III & COL1A1 or COL1A2 & Progressively deforming \\
\hline IV & COL1A1 or COL1A2 & Moderately deforming \\
\hline \multicolumn{3}{|l|}{ COL1-mutation negative } \\
\hline V & IFITM5 & $\begin{array}{l}\text { Moderate, distinct histology, and } \\
\text { hyperplastic callus }\end{array}$ \\
\hline $\mathrm{XV}$ & WNT1 & Mild/early onset osteoporosis \\
\hline \multicolumn{3}{|l|}{ Recessive inheritance } \\
\hline \multicolumn{3}{|l|}{ Mineralization defect } \\
\hline VI & SERPINF1 & Moderate to severe, distinct histology \\
\hline \multicolumn{3}{|l|}{ 3-Hydroxylation defects } \\
\hline VII & CRTAP & Severe to lethal \\
\hline VIII & LEPRE1 & Severe to lethal \\
\hline IX & $P P I B$ & Moderate to lethal \\
\hline \multicolumn{3}{|l|}{ Chaperone defects } \\
\hline $\mathrm{X}$ & SERPINH1 & Severe \\
\hline $\mathrm{XI}$ & FKBP10 & $\begin{array}{l}\text { Progressive deforming, Bruck } \\
\text { syndrome }\end{array}$ \\
\hline \multicolumn{3}{|l|}{ Zinc-finger transcription factor defect } \\
\hline XII & $S P 7$ & Moderate \\
\hline \multicolumn{3}{|l|}{ C-propeptide cleavage defect } \\
\hline XIII & $B M P 1$ & Severe, high bone mass case \\
\hline \multicolumn{3}{|l|}{ Cation channel defect } \\
\hline XIV & TMEM38B & Moderate to severe \\
\hline \multicolumn{3}{|l|}{ WNT signaling pathway defect } \\
\hline XV & WNT1 & Moderate, progressively deforming \\
\hline Unclassified ER stresstransducer deficiency & CREB3L1 & Severe \\
\hline \multicolumn{3}{|l|}{ X-linked inheritance } \\
\hline Unclassified suspected osteocyte defect & PLS3 & Mild \\
\hline
\end{tabular}

\section{Classification}

OI has traditionally been classified according to Sillence, who published a revised classification system based on clinical, radiological, and hereditary findings in the late 1970s (33, 34, 35) (Table 1). The mildest, and most common, type of OI is denoted Sillence type I. This type is associated with fractures, blue sclerae, and hearing impairment. These individuals often have multiple fractures in childhood, but improve clinically after puberty and have a normal life expectancy (36). OI type II is a perinatal lethal variant. Affected fetuses and infants are usually stillborn, or die within a few days to weeks after birth due to multiple thoracic fractures causing respiratory complications, and possibly have an intrinsic pulmonary collagen pathology (37). The most severe OI type compatible with surviving the neonatal period is type III. Individuals with OI type III may suffer hundreds of fractures, and often have a markedly short stature, progressive deformities, severe scoliosis, and a shortened life span (36). DI is common and sclera has variable hue. Sillence type IV is a moderate form, with a phenotype spanning between types I and III in severity and clinical characteristics. The Sillence classification system is widely used, although recently discovered diversity in underlying molecular background as well as the phenotypic heterogeneity of collagen I mutations complicates classification. Roman numerals have been added for every new gene discovered to cause an OI-like phenotype, and to date 17 types have been described (Table 1$)(5,6,7,8,9,10,11,12$, $13,14,15,16,17,18,19,20,21,22,23,24,25,26,27,28$, $29,30)$. The OI phenotypes caused by non-collagenous genes overlap with collagen I mutation-caused classical dominant OI, and there is no clear consensus on how to best define and classify this disorder.

\section{Pathogenesis}

Collagen type I constitutes $\sim 90 \%$ of the organic matrix of bone and supplies toughness, while the mineral 
component, hydroxyapatite, renders stiffness, and compression resilience. Collagen I is a heterotrimer composed of two $\alpha 1$ chains and one $\alpha 2$ chain encoded by the genes COL1A1 and COL1A2. The three chains associate C-terminally and in a zipperlike fashion create a highly structured triple helix that is 1014 amino acid residues long and composed of triplicate repeats of Gly-X-Y, flanked by globular $\mathrm{N}$ - and C-terminal ends. Mature collagen is formed when the globular ends are cleaved off peri-cellularly, and a meticulously ordered extracellular organic matrix can subsequently be developed and mineralized by hydroxyapatite. Principally, two types of mutations in collagen I cause classical dominant OI: quantitative and qualitative collagen defects.

Quantitative mutations are the result of haploinsufficiency of COL1A1; patients have structurally normal collagen type I, but a reduced amount. Premature stop codons and splice-site mutations or insertion/deletions are commonly observed mutation types and all cause nonsense-mediated decay of mRNA from one COL1A1 allele. Collagen type I is highly expressed in many connective tissue cell types, e.g. osteoblasts, and both alleles of COL1A1 are required to meet the needs of the organism. Haploinsufficiency of COL1A1 is usually associated with the milder type I phenotype, while COL1A2 haploinsufficiency does not have an overt clinical bone phenotype (38).

Qualitative mutations are generally glycine substitutions (80\%) or splice site mutations (20\%); however, rare $\mathrm{N}$ - and $\mathrm{C}$-terminal and $\mathrm{X}$ - and Y-position helical mutations have been described (39, 40, 41, 42, 43). Glycine is the only amino acid small enough to fit in the confined helical center of collagen I, and thus a prerequisite for correct folding. All described helical glycine substitutions cause OI phenotypes, with a severity depending on the position and specific substitution. Qualitative mutations cause a more heterogeneous phenotypic spectrum than quantitative mutations, ranging from mild disease similar to osteoporosis to perinatal lethal OI.

Non-collagenous genes causing OI are often involved in specific collagen modifications or function as collagen chaperones $(29,30,44)$. Other examples of genes associated with OI phenotype may be involved in osteoblast differentiation and signaling or bone formation $(19,20,22,45)$. Many of the recently described noncollagenous OI types have phenotypes spanning from a moderate-to-lethal end of the spectrum; possibly due to ascertainment bias since severe cases are more thoroughly investigated.

\section{Heterogeneity of disease}

Collagen mutations described so far illustrate a complex relationship between genotype and phenotype. Although some general principles can be discerned, it is virtually impossible to predict the phenotype of any given mutation with certainty. Varying phenotypes have been described for recurrent mutations, even when these are present within the same family. For example, specific glycine substitutions have been associated with both lethal and non-lethal OI (46). This phenotypic variability is thought to be caused by modifying elements, which are essentially unknown to date $(46,47)$. Similarly, this phenomenon has been described for non-collagenous OI; all known OI types $\mathrm{V}$ cases are caused by the same mutation in the IFITM5 gene, but there is pronounced variability even within the same family regarding phenotypic severity (48). Also, individuals with OI type IX, caused by similar nonsense mutations in cyclophilin B (encoded by PPIB), exhibit a moderate-to-severe phenotype $(9,27)$. Generally, for collagen I mutations, it has been established that COL1A1 mutations are more often associated with a lethal phenotype than COL1A2 mutations (46). Glycine substitutions located at the $\mathrm{N}$-terminal part are non-lethal in both genes (46). Glycine substitutions for large, branched, and charged amino residues are more often associated with a severe phenotype (46). In the collagen $\alpha 1$ (I) chain at helical positions 691-823 and 910-964, consisting of major ligand-binding regions (MLRBs), essentially only lethal substitutions are identified. The MLRBs include sites important for collagen self-assembly and cleavage, as well as for binding by integrins, fibronectin, and other factors (46). For the noncollagenous mutations, only few cases have been reported and phenotypic variability has not been extensively studied, and therefore general principles have not been described yet.

\section{Treatment of 0}

The focus of this review is on pharmacological treatment of adult OI. However, pharmacological treatment cannot stand alone, and physiotherapy, habilitation, and orthopedic care in the hands of an experienced surgeon from infancy are of utmost importance for more severe forms of OI.

\section{Bone-specific treatments}

There are a number of pharmacological agents available for effective fracture reduction in postmenopausal and 
male osteoporosis, such as bisphosphonates (e.g. alendronate and zoledronate), monoclonal RANKL antibody (denosomab), and rPTH (1-34) (teriparatide). These agents either attenuate loss of bone mass or increase bone mass, and thus decrease the risk of fracture. In OI, however, the pathophysiology of the disease causes a defective bone matrix, which does not necessarily respond to these pharmaceutical agents by a decrease in fracture rate. Generally, bone-specific treatments are prescribed together with calcium and vitamin D supplementation. Recent studies of treatment for postmenopausal osteoporosis have shown that adequate response to, for example, bisphosphonate treatment is correlated with circulating levels of $25(\mathrm{OH}) \mathrm{D}(49,50)$. For treatment of OI, this would indicate that low serum $25(\mathrm{OH}) \mathrm{D}$, as well as inadequate calcium intake, should be supplemented, unless contraindications are present.

There is currently no satisfactory treatment for severe OI, despite decades of research. Research in stem-cell transplantation $(51,52,53)$ and various gene therapies $(54,55,56,57,58)$ have not yielded clinically available applications. Individuals with mild OI are treated conservatively in most centers. In moderateto-severe cases, with multiple long-bone fractures and/or vertebral compression fractures, bisphosphonate treatment is being used in children and often initiated at a young age, even in infancy $(59,60,61,62,63)$. However, considerably less is known about how best to treat adults with moderate-to-severe OI, as only few trials, each comprising small numbers of treated patients with different OI types, have been published. As the patient population with OI grows older, the deleterious effects on the skeleton from aging are superimposed on the already present diminished bone mass and inferior bone quality due to the underlying disease. Furthermore, it is important to emphasize that the long-term effects of bisphosphonate treatment in pediatric and adult OI are not known.

\section{Bisphosphonate treatment for OI in childhood}

There is evidence from animal studies that bisphosphonate treatment leads to increases in BMD as well as decreases in fracture rate, as exemplified in the oim/oim mouse model of OI (64). In humans, bisphosphonates have been shown to increase lumbar spine BMD, ameliorate negative bone phenotypes, and improve vertebral height and areal measurements in children with OI $(59,61,63,65,66,67)$. However, initial reports on decreased pain and improved ambulation regrettably have not been possible to replicate in later controlled trials, and data on fracture reduction are equivocal $(62,63,68)$. Recently a randomised, double-blind, placebo-controlled trial of orally administrated risedronate in children with predominantly mild OI has demonstrated a reduction in the rate of clinical fractures (69). Such trials have not been carried out with i.v. pamidronate for severe OI, and we therefore have no evidence for fracture reduction in this group of patients. Considering that i.v. bisphosphonates are routinely used in the treatment of severe OI (63), a randomized, placebocontrolled study would be difficult to perform. Regarding safety concerns with bisphosphonate treatment in OI, there have been no reports of osteonecrosis of the jaw neither in treated children, nor young adults up to age 25 , despite the relatively high doses of bisphosphonate treatment given to children with OI $(70,71)$. Atypical femur fracture is another very rare condition that has been observed in patients on bisphosphonate therapy for osteoporosis (72). The only published observational study on this issue in OI for pediatric and adolescent patients highlights the need for further research regarding atypical femur fractures in bisphosphonate-treated patients with OI (73).

BMD treatment response in relation to BMD at onset and age at initiation has not been thoroughly studied in OI patients; however, there are reports supporting a negative correlation to BMD at onset $(67,74)$. Infants as young as 2 months have been treated with promising results and safety data $(59,60,61,75)$, and according to one study younger children did not gain as much bone compared with older children, explained by the fact that the deficit in BMD was smaller in younger children (67). Another study considered the response in infants to be faster and more pronounced than that in older children (75). Furthermore, although the majority of studies of bisphosphonate treatment are on children older than 3 years of age, there is support in observational trials with historical controls for increased BMD, improved vertebral shape, and attainment of motor milestones at an earlier age when treating severely affected infants with pamidronate $(59,61)$.

\section{Bisphosphonate treatment for Ol in adults}

There are more studies on use of bisphosphonate in pediatric than in adult OI populations and some of the positive outcomes seen in children have been difficult to demonstrate in adults (76), although the overall goals of treatment are the same: reduction in fractures and chronic 
bone pain and increase in BMD as a surrogate marker for treatment effect.

Table 2 summarizes the published Cochrane Systematic Reviews from 2008 (63), and studies on treatment of adult OI published since. In the Cochrane review from, the effectiveness and safety of bisphosphonates in treatment of OI in children and adults in randomized and quasirandomized controlled trials comparing bisphosphonates with placebo, no treatment, or comparator interventions, in all types of OI was presented (63). Publications were included up to publication date of August 2008, with two studies available for analysis for the adult population (Table 2) $(77,78)$. The study by Chevrel et al. (78) on 64 adult OI patients in a 3-year randomized placebocontrolled study of alendronate showed a significant increase in total hip and lumbar spine BMD, but no significant difference in fracture rate, although the study was not statistically powered for analyses of fracture. Adami et al. (77) studied 46 OI adults, in which 31 received i.v. neridronate, compared with 15 patients who did not receive treatment until cross over after 12 months. Total follow-up time was 24 months, and a trend toward statistical significance was reported when pooling prerecruitment and study period fracture rates, in favor of treatment.

After the publication of the Cochrane review, an additional four studies have been published on bisphosphonate treatment of adult OI patients. In a prospective non-randomized study of zoledronic acid in ten patients with osteoporosis or severe osteopenia $(T$ score $<-2$ ) related to OI who could not tolerate oral bisphosphonates, Pavon de Paz et al. (79) found increases in lumbar spine BMD at 24 and 36 months and increase in femoral neck at 24 months. No fractures occurred in the patients during the study period. Shapiro et al. carried out an observational, nonrandomized study of 90 OI adults treated either with i.v. pamidronate $(n=28)$, oral alendronate $(n=10)$, or oral risedronate $(n=17)$. The untreated control group consisted of 35 patients (76). For type I OI, all bisphosphonates were associated with BMD increase in lumbar spine, and for the oral bisphosphonates increases in total hip were seen. A reduction in fracture rate was only seen for i.v. pamidronate in type III/IV patients (76). In a retrospective study of 16 adult patients with OI in Ireland, O'Sullivan et al. showed a large increase in BMD in patients on bisphosphonate treatment (median increase $15.1 \% ; n=10$ ), and for two patients on PTH treatment (40.3 and 27.2\% increase respectively) (80). No conclusions on fracture rate reduction could be drawn. In a prospective study by
Bradbury et al. (81), 27 patients with type I OI treated with oral risedronate $35 \mathrm{mg}$ weekly were assessed over 24 months. BMD increased significantly at lumbar spine $(3.9 \%)$, with no change in total hip. Fracture rate remained at the level of historical controls.

\section{Teriparatide treatment in Ol in adults}

Teriparatide stimulates bone formation and reduces vertebral and non-vertebral fractures in postmenopausal osteoporosis (82). As OI is characterized by reduced collagen production and thereby bone formation, it seems obvious to investigate the effect of teriparatide in adult patients with OI. Observational studies have shown a positive effect on BMD in postmenopausal women $(n=13)$, with a statistically significant $3.5 \%$ increase in lumbar spine BMD (83). Orwoll et al. investigated in a randomized, placebo-controlled study comprising 79 adult OI patients, predominantly type I, the effect of teriparatide vs placebo over 18 months. Lumbar spine and hip BMD increased significantly in the patients treated with teriparatide compared with patients treated with placebo. Also markers of bone turnover increased significantly in the treated patients. No difference in selfreported fractures could be demonstrated between the two groups. Furthermore, although the number of patients with OI types III and IV were limited, subgroup analyses indicated that the effect was attenuated among these patients compared with type I OI patients (84). Further studies are needed to clarify whether treatment with teriparatide is superior to treatment with bisphosphonates or other antiresorptives in adult patients with different types of OI.

\section{Other potential treatments for OI}

There are a number of therapies under evaluation for OI (e.g. the more recent osteoporosis treatments with denosomab and sclerostin antibodies), as well as therapies under development (e.g. cell-based therapies), and experimental models presently in vitro and in animals. These different areas of possible future therapies for OI are further described later.

Cell-based therapy $\bullet$ Parental somatic mosaicism is thought to underlie about $5 \%$ of classical OI, and the observation that these mosaic parents are phenotypically normal has provided rationale for different cell-based therapies. It has been proposed that normal osteoblasts in mosaic individuals have an advantage over osteoblasts 


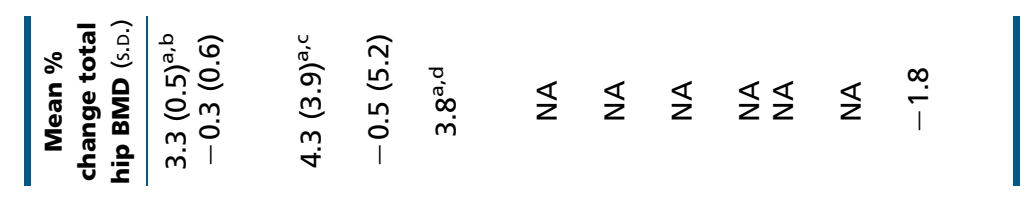

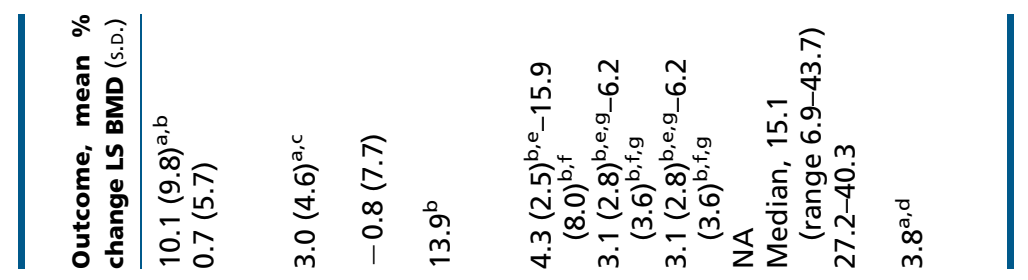



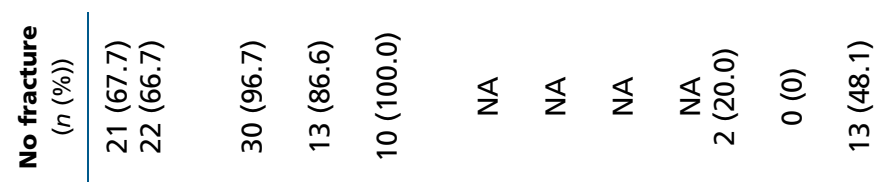

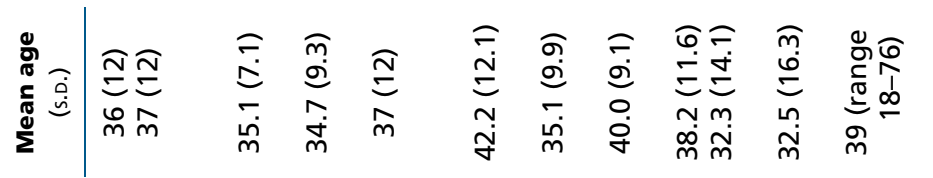



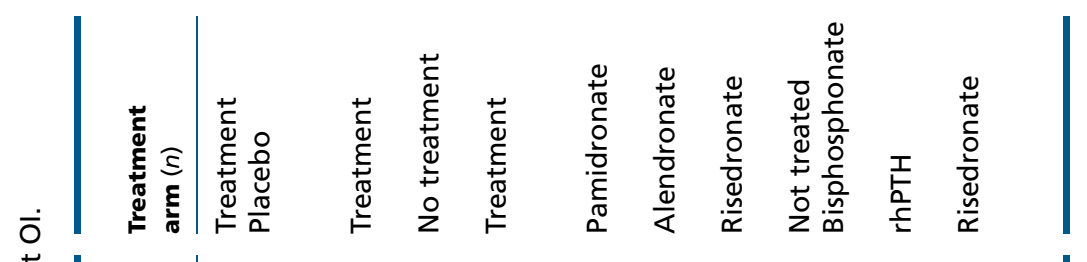

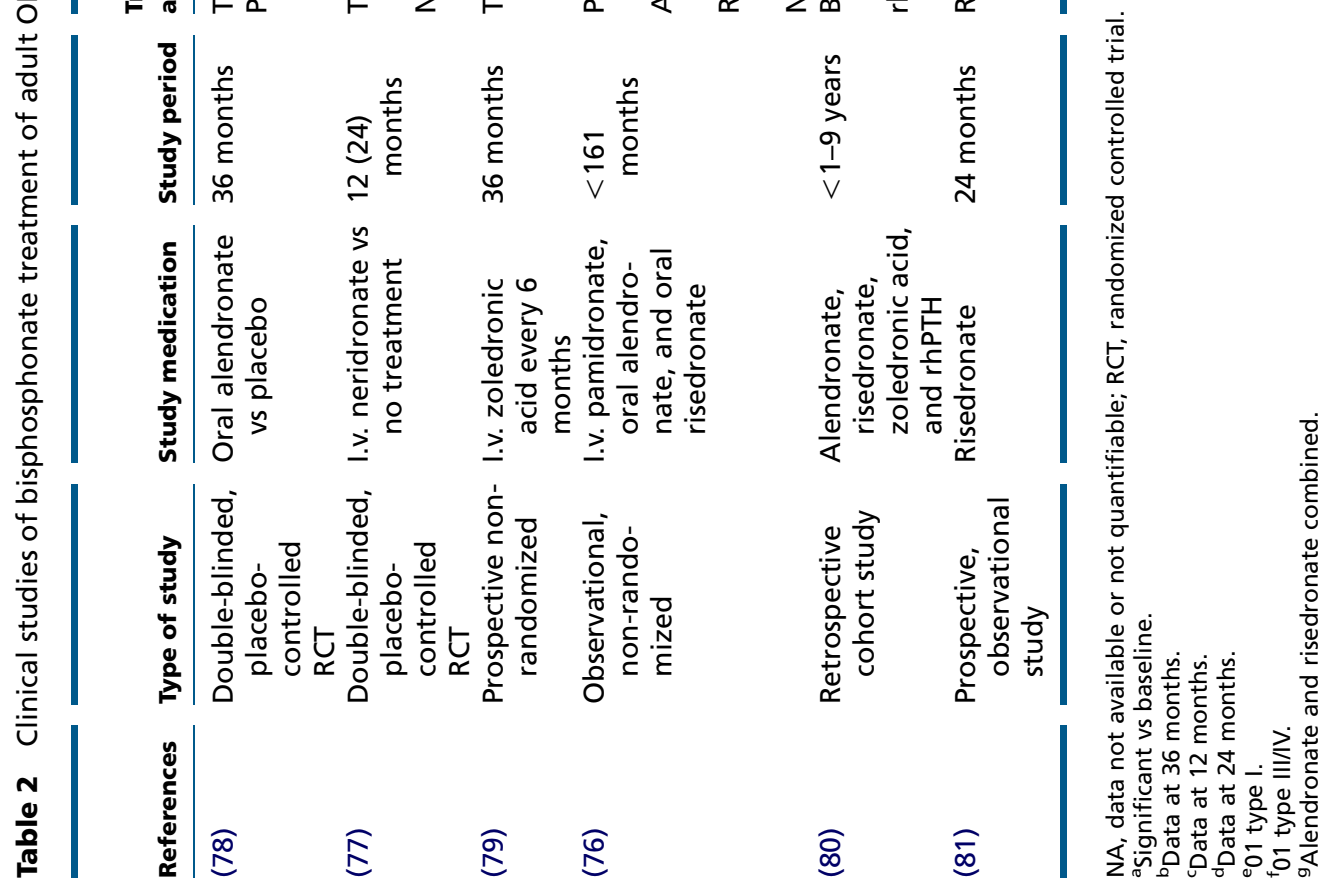


producing mutated collagen. Thus, if normal osteoblasts could be introduced to an OI patient, these may mimic the situation in a mosaic carrier of OI, with the normal cells outperforming mutation-harboring cells $(85,86)$. Along these lines, bone marrow transplantation has been carried out in OI patients in clinical trials, aiming at introducing normal osteoblasts through differentiation of mesenchymal stem cells. A few positive reports have been published, despite low numbers of engrafted cells $(51,52,53)$. Induced pluripotent cells could be another possible option (87); these could potentially be engineered to produce any desired tissue, including bone-forming cells for OI patients. This approach has been studied in vitro in mesenchymal cells from OI patients (88).

Gene therapy $>$ Allele-specific gene silencing $>$ For severe dominant OI, a therapeutic vision is silencing the mutated allele by gene therapy, i.e. allele-specific silencing. For a COL1A1 mutation, the consequence would be COL1A1 haploinsufficiency, thus converting a severe phenotype to mild OI (similar to type I). Heterozygous COL1A2 null alleles have no overt phenotype.

There are several publications that report successful allele-specific gene silencing using siRNAs discriminating between single-nucleotide variants within specific mRNAs $(89,90,91,92,93,94,95,96,97)$. These studies suggest that siRNAs may be interesting to explore as therapeutics in dominant monogenetic disorders such as dominant OI as well and the first steps toward allelespecific silencing in OI were taken in 2004 in a study which reports that COL1A1 was silenced in mesenchymal progenitor cells (98). A recent publication has reported that allele-specific silencing of COL1A1 using short hairpin RNAs (shRNAs) reduced the amount of mutant collagen in Brtl/ + mice, a murine model for classical dominant OI (58). Targeted cell delivery is a challenge, and it will be necessary to guide siRNAs specifically to the cells in sufficient quantity. Possible avenues investigated include viral vectors expressing target tissue-specific shRNAs, aptamer-shRNA chimeras as well as atelocollagen-bound siRNAs $(58,99,100)$.

For OI, more than 800 qualitative mutations have been described in COL1A1 and COL1A2 $(46,101)$, making it prohibitively laborious to create unique siRNAs for each mutation. A mutation-independent approach is desirable, and targeting of heterozygous SNPs (102) or insertion/ deletion polymorphisms (indels) (103) in the COL1A1 and COL1A2 genes has now been successfully carried out in human bone cells in vitro. By specifically targeting both alleles of a common heterozygous position, all heterozygous individuals carrying a mutation on the same allele (in cis) could be treated, and design of a limited number of highly specific siRNAs with minimal off-target effects would potentially treat a majority of patients.

Viral vectors as a potential approach for recessive OI $\bullet$ For many recessive disorders even a moderate increase in gene product can have a crucial effect on biological activity and function, and for OI such an increase could potentially rescue the recessive phenotypes. The most common approach for this would be utilizing a viral vector introducing a cDNA copy of the missing allele, with the largest conferred risk being turning on an oncogene or turning off a tumor suppressor gene. Several studies using viral vectors are ongoing for a multitude of disorders (104); however, to date there are no publications describing the use of viral vectors in recessive OI.

Ex vivo correction of mutated allele - OI type I is often due to a quantitative collagen defect, and gene correction of the mutated allele or enhanced activity of the functioning allele would be the desirable goal. However, COL1A1 is a highly expressed large gene, and the viral vector approach described earlier would most likely not be optimal for classical dominant OI type I. Furthermore, for qualitative mutations, enhanced activity of the functioning allele would have to be combined with silencing of the mutated allele as OI is a dominant disorder. An attractive avenue for dominant OI would be a correction of the mutant allele with subsequent return of the corrected cells to the affected individual. Steps in this direction are ongoing through use of e.g. zinc-finger nucleases (105) and TALEN systems (106) and hopefully this approach can be applied for patients with OI in the future.

Other pharmaceutical approaches $>$ Over the years many different treatment regimes for OI have been studied with equivocal clinical effects following on initially positive publications; e.g. cortisone, vitamin A, vitamin $\mathrm{D}$, fluoride, and strontium ranelate, as well as the hormones calcitonin, thyroxin, estrogens, and androgens. The combination of recombinant growth hormone (rGH) and bisphosphonates is still under investigation and may be beneficial for OI types I, IV, and III to increase linear growth, although these patients are not endogenously GH deficient (107).

Little is known about the benefits of other osteoporosis therapies for OI patients. The RANKL antibody, denosumab, was well tolerated in a small scale study in recessive OI 
(108), and sclerostin antibody, an emerging osteoporosis therapeutic, has been shown to act as an anabolic agent in the type III OI murine model Brtl/ + (109).

\section{Future perspectives}

Larger study cohorts are needed to properly investigate the efficacy of pharmacological intervention, and efforts are underway to have national and international OI registries to make this possible.

Such registries/cohorts could also be the basis for further research into genotype vs phenotype for prediction of disease severity, and pharmacogenetic studies on the choice of medical treatment based on the patient's mutation.

\section{Summary}

Bisphosphonates are the most widely investigated and used treatment option for OI, and have been shown to increase BMD in both children and adults, while effects on fracture incidence remain equivocal. For adults, there are few randomized controlled studies for treatment of OI, and the evidence for treatment is therefore limited. A recently published study of the effects of teriparatide in adult OI has shown positive effects on BMD, at least in mild disease. Despite the lack of evidence, bisphosphonates are being used for the prevention of fractures in adult OI, although dosing and duration of treatment remain to be studied further.

Trials investigating the effects of novel bone-specific treatments approved for use in postmenopausal osteoporosis in adult patients with OI are ongoing. Gene therapy may be a possible future treatment option for severe OI. Larger cohorts of patients with OI are necessary to obtain the statistical power to perform genotype/ phenotype studies, pharmacogenetic studies and to assess fracture efficacy of bone-specific medications.

\section{Declaration of interest}

The authors declare the following association with the companies: K Lindahl disclosures: speaker's bureau for Amgen. B Langdahl disclosures: received research grant from Eli Lilly, advisory boards and speaker's bureau for Eli Lilly, Merck, Sharp \& Dohme, and Amgen. Ö Ljunggren disclosures: speaker's bureau for Eli Lilly and Amgen. A Kindmark disclosures: research grant and speaker's bureau for Shire HGT, speaker's bureau for Amgen and Glaxo Smith Kline. Inventor on patents WO2007039724, WO2007039718, WO2007039722, and WO2007039721.

\section{Funding}

This review did not receive any specific grant from any funding agency in the public, commercial or not-for-profit sector.

\section{References}

1 Andersen PE Jr \& Hauge M. Osteogenesis imperfecta: a genetic, radiological, and epidemiological study. Clinical Genetics 198936 250-255. (doi:10.1111/j.1399-0004.1989.tb03198.x)

2 Kuurila K, Kaitila I, Johansson R \& Grenman R. Hearing loss in Finnish adults with osteogenesis imperfecta: a nationwide survey. Annals of Otology, Rhinology, and Laryngology $2002111939-946$.

3 Orioli IM, Castilla EE \& Barbosa-Neto JG. The birth prevalence rates for the skeletal dysplasias. Journal of Medical Genetics 198623 328-332. (doi:10.1136/jmg.23.4.328)

4 Stoll C, Dott B, Roth MP \& Alembik Y. Birth prevalence rates of skeletal dysplasias. Clinical Genetics 198935 88-92. (doi:10.1111/j.1399-0004. 1989.tb02912.x)

5 Sykes B, Ogilvie D, Wordsworth P, Anderson J \& Jones N. Osteogenesis imperfecta is linked to both type I collagen structural genes. Lancet 19862 69-72. (doi:10.1016/S0140-6736(86)91609-0)

6 Morello R, Bertin TK, Chen Y, Hicks J, Tonachini L, Monticone M, Castagnola P, Rauch F, Glorieux FH, Vranka J et al. CRTAP is required for prolyl 3-hydroxylation and mutations cause recessive osteogenesis imperfecta. Cell 2006127 291-304. (doi:10.1016/j.cell. 2006.08.039)

7 Barnes AM, Chang W, Morello R, Cabral WA, Weis M, Eyre DR, Leikin S, Makareeva E, Kuznetsova N, Uveges TE et al. Deficiency of cartilage-associated protein in recessive lethal osteogenesis imperfecta. New England Journal of Medicine 2006355 2757-2764. (doi:10.1056/ NEJMoa063804)

8 Cabral WA, Chang W, Barnes AM, Weis M, Scott MA, Leikin S, Makareeva E, Kuznetsova NV, Rosenbaum KN, Tifft CJ et al. Prolyl 3-hydroxylase 1 deficiency causes a recessive metabolic bone disorder resembling lethal/severe osteogenesis imperfecta. Nature Genetics 2007 39 359-365. (doi:10.1038/ng1968)

9 Barnes AM, Carter EM, Cabral WA, Weis M, Chang W, Makareeva E, Leikin S, Rotimi CN, Eyre DR, Raggio CL et al. Lack of cyclophilin B in osteogenesis imperfecta with normal collagen folding. New England Journal of Medicine 2010362 521-528. (doi:10.1056/ NEJMoa0907705)

10 van Dijk FS, Nesbitt IM, Zwikstra EH, Nikkels PG, Piersma SR, Fratantoni SA, Jimenez CR, Huizer M, Morsman AC, Cobben JM et al. PPIB mutations cause severe osteogenesis imperfecta. American Journal of Human Genetics 200985 521-527. (doi:10.1016/j.ajhg. 2009.09.001)

11 Baldridge D, Schwarze U, Morello R, Lennington J, Bertin TK, Pace JM, Pepin MG, Weis M, Eyre DR, Walsh J et al. CRTAP and LEPRE1 mutations in recessive osteogenesis imperfecta. Human Mutation 2008 29 1435-1442. (doi:10.1002/humu.20799)

12 Alanay Y, Avaygan H, Camacho N, Utine GE, Boduroglu K, Aktas D, Alikasifoglu M, Tuncbilek E, Orhan D, Bakar FT et al. Mutations in the gene encoding the RER protein FKBP65 cause autosomal-recessive osteogenesis imperfecta. American Journal of Human Genetics $2010 \mathbf{8 6}$ 551-559. (doi:10.1016/j.ajhg.2010.02.022)

13 Kelley BP, Malfait F, Bonafe L, Baldridge D, Homan E, Symoens S, Willaert A, Elcioglu N, Van Maldergem L, Verellen-Dumoulin C et al. Mutations in FKBP10 cause recessive osteogenesis imperfecta and Bruck syndrome. Journal of Bone and Mineral Research 201126 666-672. (doi:10.1002/jbmr.250)

14 Christiansen HE, Schwarze U, Pyott SM, AlSwaid A, Al Balwi M, Alrasheed S, Pepin MG, Weis MA, Eyre DR \& Byers PH. Homozygosity for a missense mutation in SERPINH1, which encodes the collagen 
chaperone protein HSP47, results in severe recessive osteogenesis imperfecta. American Journal of Human Genetics 201086 389-398. (doi:10.1016/j.ajhg.2010.01.034)

15 Becker J, Semler O, Gilissen C, Li Y, Bolz HJ, Giunta C, Bergmann C, Rohrbach M, Koerber F, Zimmermann K et al. Exome sequencing identifies truncating mutations in human SERPINF1 in autosomalrecessive osteogenesis imperfecta. American Journal of Human Genetics 201188 362-371. (doi:10.1016/j.ajhg.2011.01.015)

16 Homan EP, Rauch F, Grafe I, Lietman C, Doll JA, Dawson B, Bertin T, Napierala D, Morello R, Gibbs R et al. Mutations in SERPINF1 cause osteogenesis imperfecta type VI. Journal of Bone and Mineral Research 201126 2798-2803. (doi:10.1002/jbmr.487)

17 Lapunzina P, Aglan M, Temtamy S, Caparros-Martin JA, Valencia M, Leton R, Martinez-Glez V, Elhossini R, Amr K, Vilaboa $\mathrm{N}$ et al. Identification of a frameshift mutation in Osterix in a patient with recessive osteogenesis imperfecta. American Journal of Human Genetics 201087 110-114. (doi:10.1016/j.ajhg.2010.05.016)

18 Martinez-Glez V, Valencia M, Caparros-Martin JA, Aglan M, Temtamy S, Tenorio J, Pulido V, Lindert U, Rohrbach M, Eyre D et al. Identification of a mutation causing deficient BMP1/mTLD proteolytic activity in autosomal recessive osteogenesis imperfecta. Human Mutation 201233 343-350. (doi:10.1002/humu.21647)

19 Laine CM, Joeng KS, Campeau PM, Kiviranta R, Tarkkonen K, Grover M, Lu JT, Pekkinen M, Wessman M, Heino TJ et al. WNT1 mutations in early-onset osteoporosis and osteogenesis imperfecta. New England Journal of Medicine 2013368 1809-1816. (doi:10.1056/ NEJMoa1215458)

20 Cho TJ, Lee KE, Lee SK, Song SJ, Kim KJ, Jeon D, Lee G, Kim HN, Lee HR, Eom HH et al. A single recurrent mutation in the $5^{\prime}$-UTR of IFITM5 causes osteogenesis imperfecta type V. American Journal of Human Genetics 201291 343-348. (doi:10.1016/j.ajhg.2012.06.005)

21 Shapiro JR, Lietman C, Grover M, Lu JT, Nagamani SC, Dawson BC, Baldridge DM, Bainbridge MN, Cohn DH, Blazo M et al. Phenotypic variability of osteogenesis imperfecta type $\mathrm{V}$ caused by an IFITM5 mutation. Journal of Bone and Mineral Research 201328 1523-1530. (doi:10.1002/jbmr.1891)

22 Shaheen R, Alazami AM, Alshammari MJ, Faqeih E, Alhashmi N, Mousa N, Alsinani A, Ansari S, Alzahrani F, Al-Owain M et al. Study of autosomal recessive osteogenesis imperfecta in Arabia reveals a novel locus defined by TMEM38B mutation. Journal of Medical Genetics 2012 49 630-635. (doi:10.1136/jmedgenet-2012-101142)

23 Volodarsky M, Markus B, Cohen I, Staretz-Chacham O, Flusser H, Landau D, Shelef I, Langer Y \& Birk OS. A deletion mutation in TMEM38B associated with autosomal recessive osteogenesis imperfecta. Human Mutation 201334 582-586.

24 van Dijk FS, Zillikens MC, Micha D, Riessland M, Marcelis CL, de Die-Smulders CE, Milbradt J, Franken AA, Harsevoort AJ \& Lichtenbelt KD. PLS3 mutations in X-linked osteoporosis with fractures. New England Journal of Medicine 2013369 1529-1536. (doi:10.1056/NEJMoa1308223)

25 Symoens S, Malfait F, S DH, Callewaert B, Dheedene A, Steyaert W, Bachinger HP, De Paepe A, Kayserili H \& Coucke PJ. Deficiency for the ER-stress transducer OASIS causes severe recessive osteogenesis imperfecta in humans. Orphanet Journal of Rare Diseases $2013 \mathbf{8} 154$. (doi:10.1186/1750-1172-8-154)

26 Pyott SM, Tran TT, Leistritz DF, Pepin MG, Mendelsohn NJ, Temme RT, Fernandez BA, Elsayed SM, Elsobky E, Verma I et al. WNT1 mutations in families affected by moderately severe and progressive recessive osteogenesis imperfecta. American Journal of Human Genetics 201392 590-597. (doi:10.1016/j.ajhg.2013.02.009)

27 Pyott SM, Schwarze U, Christiansen HE, Pepin MG, Leistritz DF, Dineen R, Harris C, Burton BK, Angle B, Kim K et al. Mutations in PPIB (cyclophilin B) delay type I procollagen chain association and result in perinatal lethal to moderate osteogenesis imperfecta phenotypes. Human Molecular Genetics 201120 1595-1609. (doi:10.1093/hmg/ ddr037)
28 Marini JC, Cabral WA \& Barnes AM. Null mutations in LEPRE1 and CRTAP cause severe recessive osteogenesis imperfecta. Cell and Tissue Research 2010339 59-70. (doi:10.1007/s00441-009-0872-0)

29 Marini JC \& Blissett AR. New genes in bone development: what's new in osteogenesis imperfecta. Journal of Clinical Endocrinology and Metabolism 201398 3095-3103. (doi:10.1210/jc.2013-1505)

30 Byers PH \& Pyott SM. Recessively inherited forms of osteogenesis imperfecta. Annual Review of Genetics 201246 475-497. (doi:10.1146/ annurev-genet-110711-155608)

31 Huang RP, Ambrose CG, Sullivan E \& Haynes RJ. Functional significance of bone density measurements in children with osteogenesis imperfecta. Journal of Bone and Joint Surgery. American Volume 200688 1324-1330. (doi:10.2106/JBJS.E.00333)

32 Sillence DO. Osteogenesis imperfecta nosology and genetics. Annals of the New York Academy of Sciences 1988543 1-15. (doi:10.1111/j.17496632.1988.tb55311.x)

33 Sillence DO, Rimoin DL \& Danks DM. Clinical variability in osteogenesis imperfecta-variable expressivity or genetic heterogeneity. Birth Defects Original Article Series 197915 113-129.

34 Sillence DO, Senn A \& Danks DM. Genetic heterogeneity in osteogenesis imperfecta. Journal of Medical Genetics 197916 101-116. (doi:10.1136/jmg.16.2.101)

35 Sillence DO \& Rimoin DL. Classification of osteogenesis imperfect. Lancet 19781 1041-1042. (doi:10.1016/S0140-6736(78)90763-8)

36 McAllion SJ \& Paterson CR. Causes of death in osteogenesis imperfecta. Journal of Clinical Pathology 199649 627-630. (doi:10.1136/jcp.49.8.627)

37 Thibeault DW, Pettett G, Mabry SM \& Rezaiekhaligh MM. Osteogenesis imperfecta type IIA and pulmonary hypoplasia with normal alveolar development. Pediatric Pulmonology 199520 301-306. (doi:10.1002/ppul.1950200508)

38 Schwarze U, Hata R, McKusick VA, Shinkai H, Hoyme HE, Pyeritz RE \& Byers PH. Rare autosomal recessive cardiac valvular form of Ehlers-Danlos syndrome results from mutations in the COL1A2 gene that activate the nonsense-mediated RNA decay pathway. American Journal of Human Genetics 200474 917-930. (doi:10.1086/420794)

39 Marini JC, Forlino A, Cabral WA, Barnes AM, San Antonio JD, Milgrom S, Hyland JC, Körkkö J, Prockop DJ, De Paepe A et al. Consortium for osteogenesis imperfecta mutations in the helical domain of type I collagen: regions rich in lethal mutations align with collagen binding sites for integrins and proteoglycans. Human Mutation 200728 209-221. (doi:10.1002/humu.20429)

40 Cabral WA, Makareeva E, Colige A, Letocha AD, Ty JM, Yeowell HN, Pals G, Leikin S \& Marini JC. Mutations near amino end of $\alpha 1(\mathrm{I})$ collagen cause combined osteogenesis imperfecta/Ehlers-Danlos syndrome by interference with N-propeptide processing. Journal of Biological Chemistry 2005280 19259-19269. (doi:10.1074/jbc. M414698200)

41 Cabral WA, Makareeva E, Letocha AD, Scribanu N, Fertala A, Steplewski A, Keene DR, Persikov AV, Leikin S \& Marini JC. Y-position cysteine substitution in type I collagen $(\alpha 1$ (I) R888C/p.R1066C) is associated with osteogenesis imperfecta/Ehlers-Danlos syndrome phenotype. Human Mutation 200728 396-405. (doi:10.1002/humu. 20456)

42 Makareeva E, Cabral WA, Marini JC \& Leikin S. Molecular mechanism of $\alpha 1$ (I)-osteogenesis imperfecta/Ehlers-Danlos syndrome: unfolding of an $\mathrm{N}$-anchor domain at the N-terminal end of the type I collagen triple helix. Journal of Biological Chemistry 2006281 6463-6470. (doi:10.1074/jbc.M511830200)

43 Pace JM, Wiese M, Drenguis AS, Kuznetsova N, Leikin S, Schwarze U, Chen D, Mooney SH, Unger S \& Byers PH. Defective C-propeptides of the proalpha2(I) chain of type I procollagen impede molecular assembly and result in osteogenesis imperfecta. Journal of Biological Chemistry 2008283 16061-16067. (doi:10.1074/jbc.M801982200) 
44 Forlino A, Cabral WA, Barnes AM \& Marini JC. New perspectives on osteogenesis imperfecta. Nature Reviews. Endocrinology 20117 540-557. (doi:10.1038/nrendo.2011.81)

45 Semler O, Garbes L, Keupp K, Swan D, Zimmermann K, Becker J, Iden S, Wirth B, Eysel P, Koerber F et al. A mutation in the $5^{\prime}$-UTR of IFITM5 creates an in-frame start codon and causes autosomaldominant osteogenesis imperfecta type $\mathrm{V}$ with hyperplastic callus. American Journal of Human Genetics 201291 349-357. (doi:10.1016/j. ajhg.2012.06.011)

46 Marini JC, Forlino A, Cabral WA, Barnes AM, San Antonio JD, Milgrom S, Hyland JC, Korkko J, Prockop DJ, De Paepe A et al. Consortium for osteogenesis imperfecta mutations in the helical domain of type I collagen: regions rich in lethal mutations align with collagen binding sites for integrins and proteoglycans. Human Mutation 200728 209-221. (doi:10.1002/humu.20429)

47 Daley E, Streeten EA, Sorkin JD, Kuznetsova N, Shapses SA, Carleton SM, Shuldiner AR, Marini JC, Phillips CL, Goldstein SA et al. Variable bone fragility associated with an Amish COL1A2 variant and a knock-in mouse model. Journal of Bone and Mineral Research 201025 247-261. (doi:10.1359/jbmr.090720)

48 Rauch F, Moffatt P, Cheung M, Roughley P, Lalic L, Lund AM, Ramirez N, Fahiminiya S, Majewski J \& Glorieux FH. Osteogenesis imperfecta type $\mathrm{V}$ : marked phenotypic variability despite the presence of the IFITM5 c. $-14 \mathrm{C}>\mathrm{T}$ mutation in all patients. Journal of Medical Genetics 201350 21-24. (doi:10.1136/jmedgenet-2012-101307)

49 Carmel AS, Shieh A, Bang H \& Bockman RS. The 25(OH)D level needed to maintain a favorable bisphosphonate response is $\geq 33 \mathrm{ng} / \mathrm{ml}$. Osteoporosis International 201223 2479-2487. (doi:10.1007/s00198011-1868-7)

50 Peris P, Martinez-Ferrer A, Monegal A, Martinez de Osaba MJ, Muxi A $\&$ Guanabens N. 25 Hydroxyvitamin D serum levels influence adequate response to bisphosphonate treatment in postmenopausal osteoporosis. Bone 201251 54-58. (doi:10.1016/j.bone.2012.03.026)

51 Horwitz EM, Gordon PL, Koo WK, Marx JC, Neel MD, McNall RY, Muul L \& Hofmann T. Isolated allogeneic bone marrow-derived mesenchymal cells engraft and stimulate growth in children with osteogenesis imperfecta: Implications for cell therapy of bone. PNAS 200299 8932-8937. (doi:10.1073/pnas.132252399)

52 Horwitz EM, Prockop DJ, Gordon PL, Koo WW, Fitzpatrick LA, Neel MD, McCarville ME, Orchard PJ, Pyeritz RE \& Brenner MK. Clinical responses to bone marrow transplantation in children with severe osteogenesis imperfecta. Blood 200197 1227-1231. (doi:10.1182/blood.V97.5.1227)

53 Le Blanc K, Gotherstrom C, Ringden O, Hassan M, McMahon R, Horwitz E, Anneren G, Axelsson O, Nunn J, Ewald U et al. Fetal mesenchymal stem-cell engraftment in bone after in utero transplantation in a patient with severe osteogenesis imperfecta. Transplantation 200579 1607-1614. (doi:10.1097/01.TP.0000159029. 48678.93)

54 Chamberlain JR, Deyle DR, Schwarze U, Wang P, Hirata RK, Li Y, Byers PH \& Russell DW. Gene targeting of mutant COL1A2 alleles in mesenchymal stem cells from individuals with osteogenesis imperfecta. Molecular Therapy 2008 16 187-193. (doi:10.1038/sj.mt.6300339)

55 Chamberlain JR, Schwarze U, Wang PR, Hirata RK, Hankenson KD, Pace JM, Underwood RA, Song KM, Sussman M, Byers PH et al. Gene targeting in stem cells from individuals with osteogenesis imperfecta. Science 2004303 1198-1201. (doi:10.1126/science.1088757)

56 Dawson PA \& Marini JC. Hammerhead ribozymes selectively suppress mutant type I collagen mRNA in osteogenesis imperfecta fibroblasts. Nucleic Acids Research 200028 4013-4020. (doi:10.1093/nar/28.20.4013)

57 Millington-Ward S, McMahon HP \& Farrar GJ. Emerging therapeutic approaches for osteogenesis imperfecta. Trends in Molecular Medicine 200511 299-305. (doi:10.1016/j.molmed.2005.04.006)

58 Rousseau J, Gioia R, Layrolle P, Lieubeau B, Heymann D, Rossi A, Marini JC, Trichet V \& Forlino A. Allele-specific Col1a1 silencing reduces mutant collagen in fibroblasts from Brtl mouse, a model for classical osteogenesis imperfecta. European Journal of Human Genetics 201322 667-674. (doi:10.1038/ejhg.2013.198)

59 Alcausin MB, Briody J, Pacey V, Ault J, McQuade M, Bridge C, Engelbert RH, Sillence DO \& Munns CF. Intravenous pamidronate treatment in children with moderate-to-severe osteogenesis imperfecta started under three years of age. Hormone Research in Paediatrics 201379 333-340. (doi:10.1159/000351374)

60 Astrom E, Jorulf H \& Soderhall S. Intravenous pamidronate treatment of infants with severe osteogenesis imperfecta. Archives of Disease in Childhood 200792 332-338. (doi:10.1136/adc.2006.096552)

61 Munns CF, Rauch F, Travers R \& Glorieux FH. Effects of intravenous pamidronate treatment in infants with osteogenesis imperfecta: clinical and histomorphometric outcome. Journal of Bone and Mineral Research 200520 1235-1243. (doi:10.1359/JBMR.050213)

62 Castillo H, Samson-Fang L, American Academy for Cerebral P \& Developmental Medicine Treatment Outcomes Committee Review P. Effects of bisphosphonates in children with osteogenesis imperfecta: an AACPDM systematic review. Developmental Medicine and Child Neurology 200951 17-29. (doi:10.1111/j.1469-8749.2008.03222.x)

63 Phillipi CA, Remmington T \& Steiner RD. Bisphosphonate therapy for osteogenesis imperfecta. Cochrane Database of Systematic Reviews 2008 CD005088. (doi:10.1002/14651858.CD005088.pub2)

64 Camacho NP, Raggio CL, Doty SB, Root L, Zraick V, Ilg WA, Toledano TR \& Boskey AL. A controlled study of the effects of alendronate in a growing mouse model of osteogenesis imperfecta. Calcified Tissue International 200169 94-101. (doi:10.1007/ s002230010045)

65 Bachrach LK \& Ward LM. Clinical review 1: Bisphosphonate use in childhood osteoporosis. Journal of Clinical Endocrinology and Metabolism 200994 400-409. (doi:10.1210/jc.2008-1531)

66 Land C, Rauch F, Munns CF, Sahebjam S \& Glorieux FH. Vertebral morphometry in children and adolescents with osteogenesis imperfecta: effect of intravenous pamidronate treatment. Bone 200639 901-906. (doi:10.1016/j.bone.2006.04.004)

67 Rauch F, Plotkin H, Zeitlin L \& Glorieux FH. Bone mass, size, and density in children and adolescents with osteogenesis imperfecta: effect of intravenous pamidronate therapy. Journal of Bone and Mineral Research 200318 610-614. (doi:10.1359/jbmr.2003.18.4.610)

68 Letocha AD, Cintas HL, Troendle JF, Reynolds JC, Cann CE, Chernoff EJ, Hill SC, Gerber LH \& Marini JC. Controlled trial of pamidronate in children with types III and IV osteogenesis imperfecta confirms vertebral gains but not short-term functional improvement. Journal of Bone and Mineral Research 200520 977-986. (doi:10.1359/ JBMR.050109)

69 Bishop N, Adami S, Ahmed SF, Anton J, Arundel P, Burren CP, Devogelaer JP, Hangartner T, Hosszu E, Lane JM et al. Risedronate in children with osteogenesis imperfecta: a randomised, double-blind, placebo-controlled trial. Lancet 2013382 1424-1432. (doi:10.1016/ S0140-6736(13)61091-0)

70 Chahine C, Cheung MS, Head TW, Schwartz S, Glorieux FH \& Rauch F. Tooth extraction socket healing in pediatric patients treated with intravenous pamidronate. Journal of Pediatrics 2008153 719-720. (doi:10.1016/j.jpeds.2008.05.003)

71 Malmgren B, Astrom E \& Soderhall S. No osteonecrosis in jaws of young patients with osteogenesis imperfecta treated with bisphosphonates. Journal of Oral Pathology \& Medicine 200837 196-200. (doi:10.1111/j.1600-0714.2007.00607.x)

72 Khosla S, Bilezikian JP, Dempster DW, Lewiecki EM, Miller PD, Neer RM, Recker RR, Shane E, Shoback D \& Potts JT. Benefits and risks of bisphosphonate therapy for osteoporosis. Journal of Clinical Endocrinology and Metabolism 201297 2272-2282. (doi:10.1210/jc.2012-1027)

73 Nicolaou N, Agrawal Y, Padman M, Fernandes JA \& Bell MJ. Changing pattern of femoral fractures in osteogenesis imperfecta with prolonged use of bisphosphonates. Journal of Children's Orthopaedics 20126 21-27. (doi:10.1007/s11832-011-0380-0) 
74 Zacharin M \& Bateman J. Pamidronate treatment of osteogenesis imperfecta - lack of correlation between clinical severity, age at onset of treatment, predicted collagen mutation and treatment response. Journal of Pediatric Endocrinology \& Metabolism 200215 163-174. (doi:10.1515/JPEM.2002.15.2.163)

75 Plotkin H, Rauch F, Bishop NJ, Montpetit K, Ruck-Gibis J, Travers R \& Glorieux FH. Pamidronate treatment of severe osteogenesis imperfecta in children under 3 years of age. Journal of Clinical Endocrinology and Metabolism 200085 1846-1850.

76 Shapiro JR, Thompson CB, Wu Y, Nunes M \& Gillen C. Bone mineral density and fracture rate in response to intravenous and oral bisphosphonates in adult osteogenesis imperfecta. Calcified Tissue International 201087 120-129. (doi:10.1007/s00223-010-9383-y)

77 Adami S, Gatti D, Colapietro F, Fracassi E, Braga V, Rossini M \& Tato L. Intravenous neridronate in adults with osteogenesis imperfecta. Journal of Bone and Mineral Research 200318 126-130. (doi:10.1359/ jbmr.2003.18.1.126)

78 Chevrel G, Schott AM, Fontanges E, Charrin JE, Lina-Granade G, Duboeuf F, Garnero P, Arlot M, Raynal C \& Meunier PJ. Effects of oral alendronate on BMD in adult patients with osteogenesis imperfecta: a 3-year randomized placebo-controlled trial. Journal of Bone and Mineral Research 200621 300-306. (doi:10.1359/JBMR.051015)

79 Pavon de Paz I, Iglesias Bolanos P, Duran Martinez M, Olivar Roldan J, Guijarro De Armas G \& Parra Garcia JI. Effects of zoledronic acid in adults with osteogenesis imperfecta. Endocrinología y Nutricióo 2010 57 245-250. (doi:10.1016/j.endonu.2010.03.017)

80 O'Sullivan ES, van der Kamp S, Kilbane M \& McKenna M. Osteogenesis imperfecta in adults: phenotypic characteristics and response to treatment in an Irish cohort. Irish Journal of Medical Science 2013183 225-230. (doi:10.1007/s11845-013-0995-x)

81 Bradbury LA, Barlow S, Geoghegan F, Hannon RA, Stuckey SL, Wass JA, Russell RG, Brown MA \& Duncan EL. Risedronate in adults with osteogenesis imperfecta type I: increased bone mineral density and decreased bone turnover, but high fracture rate persists. Osteoporosis International 201223 285-294. (doi:10.1007/s00198-011-1658-2)

82 Neer RM, Arnaud CD, Zanchetta JR, Prince R, Gaich GA, Reginster JY, Hodsman AB, Eriksen EF, Ish-Shalom S, Genant HK et al. Effect of parathyroid hormone (1-34) on fractures and bone mineral density in postmenopausal women with osteoporosis. New England Journal of Medicine 2001344 1434-1441. (doi:10.1056/NEJM200105103441904)

83 Gatti D, Rossini M, Viapiana O, Povino MR, Liuzza S, Fracassi E, Idolazzi L \& Adami S. Teriparatide treatment in adult patients with osteogenesis imperfecta type I. Calcified Tissue International 201393 448-452. (doi:10.1007/s00223-013-9770-2)

84 Orwoll ES, Shapiro J, Veith S, Wang Y, Lapidus J, Vanek C, Reeder JL, Keaveny TM, Lee DC, Mullins MA, Nagamani SC \& Lee B. Evaluation of teriparatide treatment in adults with osteogenesis imperfecta. Journal of Clinical Investigation 2014124 491-498. (doi:10.1172/ JCI71101)

85 Otsu M, Sugamura K \& Candotti F. In vivo competitive studies between normal and common gamma chain-defective bone marrow cells: implications for gene therapy. Human Gene Therapy 200011 2051-2056. (doi:10.1089/10430340050143462)

86 Roberts C, Kean L, Archer D, Balkan C \& Hsu LL. Murine and math models for the level of stable mixed chimerism to cure $\beta$-thalassemia by nonmyeloablative bone marrow transplantation. Annals of the New York Academy of Sciences 20051054 423-428. (doi:10.1196/annals. 1345.061)

87 Yamanaka S. Induced pluripotent stem cells: past, present, and future. Cell Stem Cell 201210 678-684. (doi:10.1016/j.stem.2012.05.005)

88 Deyle DR, Khan IF, Ren G, Wang PR, Kho J, Schwarze U \& Russell DW. Normal collagen and bone production by gene-targeted human osteogenesis imperfecta iPSCs. Molecular Therapy 201220 204-213. (doi:10.1038/mt.2011.209)

89 Atkinson SD, McGilligan VE, Liao H, Szeverenyi I, Smith FJ, Moore CB $\&$ McLean WH. Development of allele-specific therapeutic siRNA for keratin 5 mutations in epidermolysis bullosa simplex. Journal of Investigative Dermatology 2011131 2079-2086. (doi:10.1038/jid. 2011.169)

90 Carroll JB, Warby SC, Southwell AL, Doty CN, Greenlee S, Skotte N, Hung G, Bennett CF, Freier SM \& Hayden MR. Potent and selective antisense oligonucleotides targeting single-nucleotide polymorphisms in the Huntington disease gene/allele-specific silencing of mutant huntingtin. Molecular Therapy 201119 2178-2185. (doi:10. 1038/mt.2011.201)

91 de Ynigo-Mojado L, Martin-Ruiz I \& Sutherland JD. Efficient allelespecific targeting of LRRK2 R1441 mutations mediated by RNAi. PLoS ONE 20116 e21352. (doi:10.1371/journal.pone.0021352)

92 Dykxhoorn DM, Schlehuber LD, London IM \& Lieberman J. Determinants of specific RNA interference-mediated silencing of human $\beta$-globin alleles differing by a single nucleotide polymorphism. PNAS 2006103 5953-5958. (doi:10.1073/pnas.0601309103)

93 Hickerson RP, Smith FJ, Reeves RE, Contag CH, Leake D, Leachman SA, Milstone LM, McLean WH \& Kaspar RL. Single-nucleotide-specific siRNA targeting in a dominant-negative skin model. Journal of Investigative Dermatology 2008128 594-605.

94 Lombardi MS, Jaspers L, Spronkmans C, Gellera C, Taroni F, Di Maria E, Donato SD \& Kaemmerer WF. A majority of Huntington's disease patients may be treatable by individualized allele-specific RNA interference. Experimental Neurology 2009217 312-319. (doi:10.1016/ j.expneurol.2009.03.004)

95 Muller GA, Hansen U, Xu Z, Griswold B, Talan MI, McDonnell NB \& Briest $\mathrm{W}$. Allele-specific siRNA knockdown as a personalized treatment strategy for vascular Ehlers-Danlos syndrome in human fibroblasts. FASEB Journal 201226 668-677. (doi:10.1096/fj.11-182162)

96 Pfister EL, Kennington L, Straubhaar J, Wagh S, Liu W, DiFiglia M, Landwehrmeyer B, Vonsattel JP, Zamore PD \& Aronin N. Five siRNAs targeting three SNPs may provide therapy for three-quarters of Huntington's disease patients. Current Biology 200919 774-778. (doi:10.1016/j.cub.2009.03.030)

97 Schwarz DS, Ding H, Kennington L, Moore JT, Schelter J, Burchard J, Linsley PS, Aronin N, Xu Z \& Zamore PD. Designing siRNA that distinguish between genes that differ by a single nucleotide. PLoS Genetics 20062 e140. (doi:10.1371/journal.pgen.0020140)

98 Millington-Ward S, McMahon HP, Allen D, Tuohy G, Kiang AS, Palfi A, Kenna PF, Humphries P \& Farrar GJ. RNAi of COL1A1 in mesenchymal progenitor cells. European Journal of Human Genetics 200412 864-866. (doi:10.1038/sj.ejhg.5201230)

99 McNamara JO II, Andrechek ER, Wang Y, Rempel RE, Gilboa E, Sullenger BA \& Giangrande PH. Cell type-specific delivery of siRNAs with aptamer-siRNA chimeras. Nature Biotechnology 200624 1005-1015. (doi:10.1038/nbt1223)

100 Ashihara E, Kawata E \& Maekawa T. Future prospect of RNA interference for cancer therapies. Current Drug Targets 201011 345-360. (doi:10.2174/138945010790711897)

101 Dalgleish R. The human collagen mutation database. Nucleic Acids Research 199826 253-255.

102 Lindahl K, Rubin CJ, Kindmark A \& Ljunggren O. Allele dependent silencing of COL1A2 using small interfering RNAs. International Journal of Medical Sciences 20085 361-365. (doi:10.7150/ijms.5.361)

103 Lindahl K, Kindmark A, Laxman N, Astrom E, Rubin CJ \& Ljunggren $\mathrm{O}$. Allele dependent silencing of collagen type I using small interfering RNAs targeting $3^{\prime}$ UTR Indels - a novel therapeutic approach in osteogenesis imperfecta. International Journal of Medical Sciences 201310 1333-1343. (doi:10.7150/ijms.5774)

104 O'Reilly M, Shipp A, Rosenthal E, Jambou R, Shih T, Montgomery M, Gargiulo L, Patterson A \& Corrigan-Curay J. NIH oversight of human gene transfer research involving retroviral, lentiviral, and adeno-associated virus vectors and the role of the NIH recombinant DNA advisory committee. Methods in Enzymology $2012507313-335$ 
105 Handel EM \& Cathomen T. Zinc-finger nuclease based genome surgery: it's all about specificity. Current Gene Therapy 201111 28-37. (doi:10.2174/156652311794520120)

106 Bedell VM, Wang Y, Campbell JM, Poshusta TL, Starker CG, Krug RG II, Tan W, Penheiter SG, Ma AC, Leung AY et al. In vivo genome editing using a high-efficiency TALEN system. Nature 2012491 114-118. (doi:10.1038/nature11537)

107 Antoniazzi F, Monti E, Venturi G, Franceschi R, Doro F, Gatti D, Zamboni G \& Tato L. GH in combination with bisphosphonate treatment in osteogenesis imperfecta. European Journal of Endocrinology 2010163 479-487. (doi:10.1530/EJE-10-0208)

108 Semler O, Netzer C, Hoyer-Kuhn H, Becker J, Eysel P \& Schoenau E. First use of the RANKL antibody denosumab in osteogenesis imperfecta type VI. Journal of Musculoskeletal \& Neuronal Interactions 2012 12 183-188.

109 Sinder BP, Eddy MM, Ominsky MS, Caird MS, Marini JC \& Kozloff KM. Sclerostin antibody improves skeletal parameters in a Brtl/+ mouse model of osteogenesis imperfecta. Journal of Bone and Mineral Research 201228 73-80. (doi:10.1002/jbmr.1717)

Received 7 January 2014

Revised version received 16 April 2014

Accepted 22 April 2014 